Article Type: Research Paper

\title{
The Role of Biological Asset Disclosure and Biological Asset Intensity in Influencing Firm Performance
}

\author{
Evy Rahman Utami ${ }^{1 *}$ and Aji Prabaswara ${ }^{2}$
}

\begin{abstract}
:
Research aims: The purpose of this study is to analyze the effect of biological asset intensity towards the firm performance with biological asset disclosure as an intervening variable.

Design/Methodology/Approach: The sample used in this study was firms engaged in the agricultural sector registered in Indonesia Stock Exchange 20152017 period. The sample selection method used was purposive sampling according to the required criteria. The analytical tools employed a mediation model based on path analysis using the software process.

Research findings: The study results showed that biological asset intensity positively affected biological asset disclosure, biological asset intensity negatively affected the firm performance, the biological asset disclosure positively affected the firm performance, and the biological asset disclosure mediated the correlation between biological asset intensity and firm performance.

Theoretical contribution/ Originality: The biological asset disclosure mediated the correlation between biological asset intensity and firm performance.

Practitioner/Policy implication: This study is expected to encourage firms to be more concerned about biological asset disclosure to improve firm performance. On the other hand, this study also helps the standard board see the biological asset disclosure in Indonesia considerably and develop the Indonesian Financial Accounting Standards Guidelines 69.

Research limitation/Implication: This study used the Indonesian Financial Accounting Standards Guidelines 69, which is relatively new for firms that effectively implement these regulations.

Keywords: Biological Asset Intensity; Biological Asset Disclosure; Firm Performance
\end{abstract}

AFFILIATION:

1,2 Department of Accounting, Faculty of Economics and Business, Universitas Muhammadiyah Yogyakarta, Yogyakarta, Indonesia.

*CORRESPONDENCE:

evy.rahman@umy.ac.id

THIS ARTICLE IS AVAILABLE IN:

http://journal.umy.ac.id/index.php/ai

DOI: 10.18196/jai.2103163

\section{CITATION:}

Utami, E.R. \& Prabaswara, A. (2020). The Role of Biological Assets Disclosure and Biological Asset Intensity in Influencing Firm Performance. Journal of Accounting and Investment, 21(3), 537-554.

\section{ARTICLE HISTORY \\ Received: \\ 27 March 2020 \\ Reviewed: \\ 30 March 2020 \\ 10 August 2020 \\ Revised: \\ 29 July 2020 \\ 27 August 2020 \\ Accepted: \\ 29 August 2020}

\section{Introduction}

Various policies and rules for measuring biological assets must be adequately treated since competition is increasingly tight among similar industries either within or outside Indonesia. Providing good financial management will produce quality financial reports and subsequently support decision making to ensure its survival (Firda, 2017). Supported by legal bases such as Law No. 40 of 2007 concerning Limited Liability Firms and Law No. 39 of 2014 concerning Plantation, it makes a firm have general direction and rules that must be adhered to in terms of financial and non-financial issues to improve its quality. 
Another matter such as information disclosure also has a legal basis issued by the government towards firms, as it is contained in Government Regulation No. 40 of 2012 concerning Limited Liability Environment and Social Responsibility and Regulation of the Minister of Environment No. 3 of 2014 concerning the Program for Assessment of Firm Performance Rating in Environmental Management. It is expected that the firm can provide appropriate information about its activities to be used as a foundation for decision making and improving external and internal relations.

Data published by the Indonesian Central Statistics Agency from 2011 to 2017 revealed the value of Gross Domestic Product (GDP) in the agricultural sector. GDP in 2014-2016 experienced a decline in growth with a GDP value of 3.25 due to a decrease in employment, which in 2015 , it was only left for $31.9 \%$, farmers' productivity reduced, and the financial reports' quality were inaccurate, so they could not be used as a foundation in decision making (Setiawan, 2017). However, there was an increase in 2018 of $3.7 \%$ to 2017 , so that it could be ascertained that GDP growth in the agricultural ${ }^{1}$ sector has improved due to the presence of the Indonesian Financial Accounting Standards Guidelines 69. It has caused an increase in the financial statements' quality (The adoption of Indonesian Financial Accounting Standards Guidelines 69 took place in 2015 but was still in draft exposure so that the firm in disclosing information regarding the use, management, and biological assets' value could increase international investors' confidence; it also increased the GDP value). Plantation firms also experienced an increase in terms of quality, as shown by the increasing land area that influenced the rising production of plantation products or commodities (BPS, 2017).

The Indonesia Stock Exchange (IDX) has summarized the firms' performance seen from their financial reports' results in various industrial fields in the first quarter of 2017. It was seen that the mining and agricultural sectors led to net profit growth, and it showed a good performance, receiving $\mathbf{1 9 8 . 2}$ for mining and 173.1 for agriculture. It indicated that the agricultural sector experienced rapid growth compared to other sectors.

It could also be increased by implementing the Indonesian Financial Accounting Standards Guidelines 69, which began to be applied in early 2018 and aims to increase agricultural firms' transparency and accountability. Biological asset disclosure is essential in the agricultural sector because when investors know how well management and maintenance are carried out by the firm, it will improve the quality of agricultural products. Good disclosure ${ }^{2}$ will increase investors' willingness to invest in agricultural firms, and it will also increase public trust related to the materials used in each processing stage of producing agricultural products (Firda, 2017). Indonesian Financial Accounting Standards Guidelines 69 elaborates that biological assets are living animals

\footnotetext{
${ }^{1}$ The agricultural sector is a sector engaged in land or agriculture and divided into several sub-sectors, such as plantation, horticulture, forestry, floriculture, fisheries, and livestock. INDONESIAN FINANCIAL ACCOUNTING STANDARDS GUIDELINES 69 describes the agricultural sector as livestock, forestry, special crops, fruit orchards, plantations, and agriculture.

${ }^{2}$ Owusu-Ansah (1998) explained that disclosure is an information communication in the economic field carried out by the firm for both financial and non-financial information, quantitative information, and other information, which shows the firm's performance and position.
} 
The Role of Biological Assets Disclosure and Biological Asset Intensity ...

or plants, which can be interpreted as assets in the form of living things experiencing biological processes, starting from born, grow, develop, produce, to the unproductive age limit, then die. Therefore, firms in carrying out the measurement process must see the biological assets' value and measure them accordingly to their effect on the firm.

Research on biological assets has been carried out by several researchers, such as Daly and Skaife (2016); Dimitrova and Velcheva (2016); Gonçalves and Lopes (2014); Selahudin, Firdaus, Sukri, Gunasegran, and Rahim (2018); and Silva, Nardi, and Ribeiro (2015). Furthermore, studies in Indonesia were conducted by Cahyani and Aprilina (2014); Farida (2013); Firda (2017); Korompis (2016); Kurniawan, Mulawarman, and Kamayanti (2015); and Wulandari and Wijayati (2018). Gonçalves and Lopes (2014) examined the value relevance of the biological assets' fair value in 27 countries that adopted IFRS until 2010. Silva et al. (2015) investigated earnings management in firms in Brazil that adopted fair value based on the discount cash flow method. The use of fair value to assess biological assets allows discretionary use when employing discounted cash flow without an active market, which affects accounting information quality (Silva et al., 2015). On the other hand, Daly and Skaife (2016) analyzed whether the accounting methods' measurement of biological assets was related to debt cost. Besides, Dimitrova and Velcheva (2016) explored the regulations and approaches to accounting for biological assets to provide solutions to make and disclose better quality information. Also, Selahudin et al. (2018) focused on examining the factors influencing the biological assets disclosure in Malaysia.

Moreover, Kurniawan et al. (2015) conducted a study to anticipate the potential danger in evaluating biological assets caused by monetary logo-centrism in accounting. On the other hand, the research done by Farida (2013) analyzed the accounting standards' implementation for biological assets at PT Perkebunan Nusantara (PTPN) VII in Bandar Lampung. Cahyani and Aprilina (2014) evaluated the SAK ETAP implementation on reporting biological assets at Unggul Farm Bogor Plantation. The method used in this study was descriptive methods. Korompis (2016) investigated the impact of the ED Indonesian Financial Accounting Standards Guidelines No. 69 implementation plan on agriculture in Coconut Agriculture in the South Likupang Region. Firda (2017) scrutinized the factors influencing biological assets' disclosure. Wulandari and Wijayati (2018) studied the biological assets' treatment in agricultural firms listed in the Indonesia Stock Exchange (IDX). Some previous studies have only proven and explained the factors influencing biological assets' disclosure. Whereas knowing the results obtained from the firms' biological asset disclosure is also one of the researchers' attention as an illustration and encouragement for firms to disclose their biological assets more broadly.

This study aimed to examine the biological asset intensity's effect on biological assets' disclosure and biological asset disclosure's effect on firm performance in agricultural firms in Indonesia. This research's motivation is to develop a model of the biological asset intensity's influence on firm performance by adding the biological asset disclosure variable as a moderating variable. Before, Murah (2017) and Gamayuni (2015) examined asset structure and asset proportion to performance. Besides, Kim, Yeo, and Zhang (2017); Kim, Park, and Lee (2018) showed that information disclosure affected firm 
performance. Latupono (2015); Rahayu and Sari (2018) also uncovered that biological assets' disclosure also impacted firm performance. Disclosure conducted by the firm would provide value-added to the firm in the form of increasing firm performance. It was because when the firm disclosed information to investors and the public, it would increase the firm's reputation so that their trust would increase and impact the increase of the firm's stock price (Sissandhy \& Sudarno, 2014). One of the factors affecting disclosure is biological asset intensity.

Biological asset intensity describes how much a firm invests its money in biological assets (Firda, 2017). Biological asset intensity can provide cash estimation that will be received if the asset is sold. Previous research carried out by Firda (2017), and Gonçalves and Lopes (2014) showed positive results related to the effect of the biological asset intensity on biological assets disclosure. Biological asset intensity is one of the factors used in testing information asymmetry (Seng \& Su, 2010).

A comparison between biological assets' proportion and the firm's total assets can affect biological assets' disclosure. The higher the firm investing its money will have a positive relationship with the biological assets' disclosure or just the opposite. Because there are still few studies using these variables in testing their influence on the biological assets' disclosure, the researchers raised these variables in this study. Choosing the biological asset intensity variable is motivated by differences in policies and rules used as the basis of measurement. Several previous studies still use IAS 41, while in Indonesia, rules have been set by the Indonesian Institute of Accountants (IAI), which are adapted to Indonesia conditions, namely Indonesian Financial Accounting Standards Guidelines 69. The researchers assume that there are different results from the influence of biological asset intensity on firm performance.

This research is a replication of previous research conducted by Ayu and Suarjaya (2017); Firda (2017); and Gonçalves and Lopes (2014), but has differences based on regulatory changes from IAS to Indonesian Financial Accounting Standards Guidelines. The differences are this study used the period of 2015-2017 because, in 2015, the Indonesian Financial Accounting Standards Guidelines 69 was still an Exposure Draft (ED), and on 1 January 2018, Indonesian Financial Accounting Standards Guidelines 69 has been approved and amended to Indonesian Financial Accounting Standards Guidelines 16. Previous studies only used the 2012-2015 period and still used IAS 41. It is expected that this study contributes to the standard board to see the biological asset disclosure in Indonesia considerably, develop, and implement Indonesian Financial Accounting Standards Guidelines 69 in Indonesia. Moreover, this study's result will enrich the literature review related to biological asset research. 


\title{
Literature Review and Hypotheses Development
}

\begin{abstract}
Agency Theory
Agency theory explains the correlation between the capital owner (principal), namely investor and manager (agent). Jensen and Meckling (1976) describe agency theory as a contract between one or more persons (principal) who hires another person (agent) to conduct a service and give authority in making a decision. The principal and agent are bounded by contract that the principal acts as the facilities and capital's provider, while the agent focuses on running the firm. It is consistent with information disclosures made by managers in reducing asymmetric information to investors so that a relationship is formed due to differences in interests between managers and investors in the process of disclosing the information. These differences in interests encourage the emergence of asymmetry information in the firm (Alvionita \& Taqwa, 2015) so that disclosing the information is as an instrument to reduce information asymmetry between firm management and external parties.
\end{abstract}

\section{Stakeholder Theory}

Freeman (1984) defines a stakeholder as "any group or individual who can affect or be affected by the achievement of an organization's objective." This theory states that all stakeholders have the right to get information about how organization activities affect them (Firda, 2017). Stakeholder theory basically describes which parties the firm is responsible for. This theory assumes the motivation of managers in disclosing information. The firm must maintain relationships with stakeholders who have power over the availability of firm resources used for firm operations. In order to maintain this relationship, the firm conducts reporting as an illustration of the firm's condition through financial statements (Sejati \& Prastiwi, 2015).

\section{Signaling Theory}

Signal theory is an action taken by firm management to give investors direction on how the management assesses its prospect (Spence, 1973). Triyani, Mahmudi, and Rosyid (2018) elaborate that a firm, which gives a signal in forms of information, can enhance the firm performance compared to other firms. The signal provides easiness for the investors to assess a firm. Positive signals generated from the information disclosed in the firm's financial statements will be well captured by investors and improve firm profitability.

This theory connects the firm's biological assets affecting its value because disclosing the information is a means of reducing asymmetric information between firm management and external parties. Thus, the firm will carry out its role as a supervisor, and it will encourage managers to focus more on improving firm performance by increasing the relationship between the firm and stakeholders (Devi, Budiasih, \& Badera 2017). It will later give a positive signal to investors regarding the firm conditions' prospects in the future. 
The Role of Biological Assets Disclosure and Biological Asset Intensity ...

\section{Biological Assets}

Indonesian Financial Accounting Standards Guidelines 69 defines a biological asset as an asset in the forms of animals or living plants. The agricultural activity includes biological transformation and harvesting assets to be sold or processed in forms agricultural products such as livestock, plantation, fishery, forestry, and others (Natasari \& Wulandari, 2018). The biological change process is a natural phenomenon in agricultural objects either in the process of growth, decline, production, or procreation caused by changes in physical and material aspects of life and brings into new assets in the form of agricultural products or additional biological assets in similar types.

When biological assets grow, there will be an increase in quality or quantity. For example, a cow will produce milk at a productive age, but it will decrease in quality and quantity when it is old. It can be categorized as a decrease in biological assets. On the other hand, procreation is the creation of additional biological assets and the production or output of biological assets in the form of milk, meat, fruits, and other things related to biological assets.

Plants in biological assets are divided into two parts: productive and non-productive plants. It is productive if (1) it is used in the production or supply of agricultural products. (2) It is expected to generate products for more than one period. (3) It has a scarce possibility to be sold as agricultural products (Indonesian Financial Accounting Standards Guidelines 69).

\section{Biological Asset Intensity and Biological Asset Disclosure}

Biological asset intensity describes the amount of money invested by the firm for the biological asset (Firda, 2017). The result of research by Firda (2017) showed that biological asset intensity affected biological asset disclosure in firms in Indonesia. On the other hand, the result of research carried out by Gonçalves and Lopes (2014) revealed a positive correlation between biological asset intensity and biological asset disclosure. Research on biological asset intensity with biological asset disclosure is usually explained using stakeholder theory, in which shareholders who have invested in the firm have privileges to know information related to the firm activities. Therefore, it obliges the firm to disclose the biological asset.

A high biological asset intensity shows the firm's belief that it will gain profit from that asset. It encourages the firm to voluntarily disclose a biological asset to show a high asset proportion. Therefore, the higher the biological asset intensity proportion, the higher the biological asset disclosure reported. Based on the previous explanation, then the first hypothesis is as follows:

$\boldsymbol{H}_{1}$ : Biological asset intensity positively affects biological asset disclosure. 
The Role of Biological Assets Disclosure and Biological Asset Intensity ...

\section{Biological Asset Intensity and Firm Performance}

Firm performance is an investor's view of its success level in increasing its stock price (Rahayu \& Sari, 2018). According to the Indonesian Financial Accounting Standards Guidelines 69, biological assets are firm-owned resources in the form of living things and can provide benefits in the future to be used as added value for the firm, create innovation, and compete in competitive businesses (Sawarjuwono \& Kadir, 2003). Biological Assets Intensity within a firm is a positive signal for the firm. The higher the firm's biological asset proportion will increase firm performance.

A research conducted by Murah (2017) examined the correlation between asset structure and firm performance in property firms listed in Indonesia Stock Exchange during the period 2013-2015. The research's results showed a positive correlation between asset structure and firm performance. Besides, a study's results by Gamayuni (2015) revealed that asset proportion affected firm performance in Indonesia. The study used manufacturing firms registered in IDX during the period 2007-2009. Based on this explanation, the second hypothesis is as follows:

$\boldsymbol{H}_{2}$ : Biological asset intensity positively affects firm performance.

\section{Biological Asset Disclosure and Firm Performance}

The research's result carried out by Kim et al. (2017) uncovered that information disclosure affected firm performance in China. The study used firms listed on the Shanghai Stock Exchange and Shenzhen Stock Exchange during the period 2008-2010. Then, Kim et al. (2018) examined the correlation between information disclosure with firm performance in Korean firms during the period 2010-2014. The study's results showed a positive relationship between information disclosure and firm performance.

Latupono (2015) illustrated that biological asset disclosure affected firm performance in Indonesia. Also, the study's results carried out by Rahayu and Sari (2018) revealed that biological asset disclosure influenced firm performance in multinational firms in Malaysia. A high information disclosure related to firm's biological assets indicates that the firm is confident that it is a positive signal in increasing firm profits. It will attract external parties and strengthen the firm's image in improving financial performance. The higher the firm's biological asset disclosure, then it is expected, the higher the financial performance produced.

Stakeholder theory states that decision making in a firm should consider expectations and demands, not only from shareholders but also from all relevant stakeholders (Kim et al., 2018). On the other hand, the agency theory explains that a firm discloses information as an instrument to reduce information asymmetry between firm management and external parties so that the firm will carry out its role as a supervisor, and it will encourage the manager to focus more on improving firm performance. 
A firm that allocates investment into firm assets indicates that it is continuously making efforts to increase its assets. Hence, the firm with high biological asset proportions will conduct broader information disclosures to increase investors' trust regarding activities carried out by the firm. It has an impact on improving firm performance because the investors will buy firm shares based on their belief that the firm will grow by considering the activities carried out. The higher the firm discloses information based on its biological asset proportion, it will improve firm performance. Based on the explanation above, the third hypothesis is as follows:

$\boldsymbol{H}_{3}$ : Biological asset disclosure positively affects firm performance.

\section{Biological Asset Intensity, Firm Performance, and Biological Asset Disclosure}

The biological asset intensity describes the cash received expectation if the assets are sold (Yurniwati, Djunid, \& Amelia 2018). Large firms with high biological assets will encourage firms to disclose more and more their biological assets. By disclosing more information, the firm is trying to imply that the firm has been applying the principles of proper corporate management (corporate governance) (Gonçalves \& Lopes, 2014). Signaling theory depicts how the information disclosed in the annual report as a positive signal affecting investors' decisions (Devi et al., 2017). Therefore, the biological asset is one of the positive signals used to take investor attention. Previous research conducted by Gonçalves and Lopes (2014) examined the factors influencing biological asset disclosure on 181 listed worldwide firms that have adopted International Financial Reporting Standards (IFRS) until 2010 and obtained results that the intensity affects biological asset disclosure. Duwu, Daat, and Andriati (2018) researched all agricultural firms in Indonesia and showed a positive influence of biological asset intensity on the broad disclosure of biological assets.

Biological assets' disclosure makes the firm has many positive signals to attract investors to invest in the firm. The more positive signals the firm has, the greater its chance to get capital from investors. The capital invested by the investor can be used to increase its capacity further and improve the firm's performance and operations. Improving the firm's quality and capacity will make the firm improve its performance. Previous research conducted by Latupono (2015) revealed that biological asset disclosure affected firm performance in Indonesia. Besides, Kim et al. (2018) conducted research on Korean firms during the period 2010-2014 and uncovered a positive relationship between information disclosure and firm performance. Based on the explanation above, the fourth hypothesis is as follows:

$\boldsymbol{H}_{4}$ : Biological asset disclosure mediates the relationship between biological asset intensity and firm performance. 
The Role of Biological Assets Disclosure and Biological Asset Intensity ...

The hypotheses in the study are summarized in the research model, as illustrated in Figure 1.

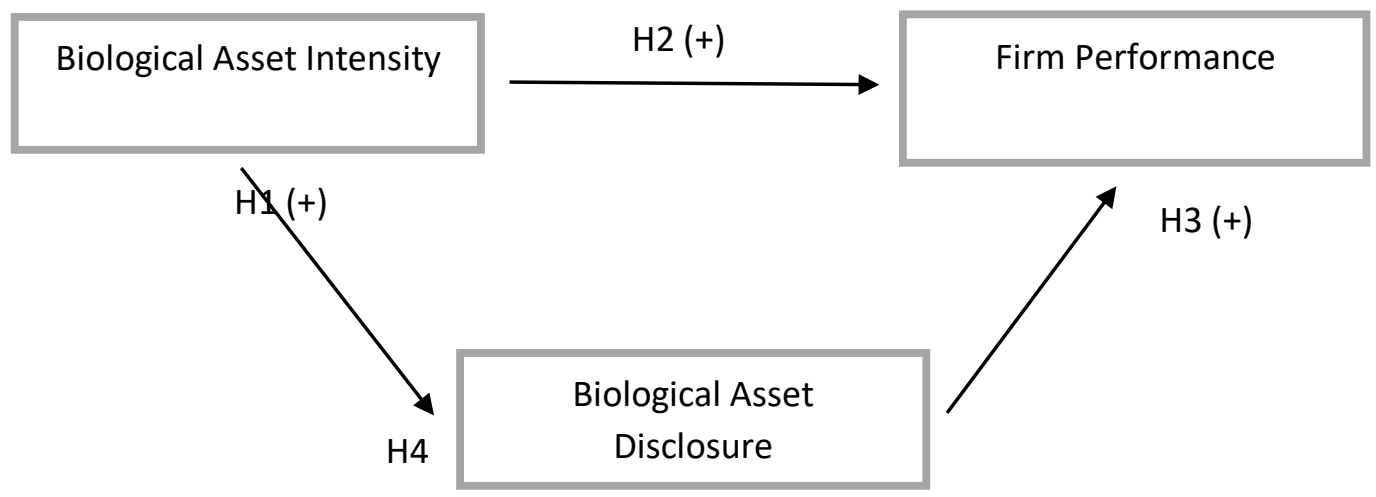

Figure 1 Research Model

\section{Research Method}

The research objects were all agricultural firms listed in Indonesia Stock Exchange 2015 - 2017 period since, in that period, IFRS had begun to be implemented. Criteria for purpose sampling were (1) 60 Agricultural firms listed in the Indonesia Stock Exchange (IDX) 2015-2017 period, (2) Agriculture firms that established an annual report, and/or financial statement. Based on the sample selection results utilizing the purposive sampling technique, 39 data samples were obtained. The sample firms that fit the criteria can be seen in the Table 1 .

Table 1 Summary of Sample Selection Process

\begin{tabular}{llc}
\hline No & \multicolumn{1}{c}{ Sample Criteria } & Total \\
\hline 1. & $\begin{array}{l}\text { Agriculture firms listed in IDX for three periods of 2015 - } \\
\text { 2017 }\end{array}$ & 60 \\
2. & Total Sample & 60 \\
3. & Data Outlier & $(21)$ \\
4. & Number of data sample processed & 39 \\
\hline
\end{tabular}

The regression equation of this study is as follows:

$$
\begin{aligned}
& B A D=\alpha+\beta_{1} B A I+e \\
& N P=\alpha+\beta_{1} B A I+e \\
& N P=\alpha+\beta_{1} B A I+\beta_{2} B A D+e
\end{aligned}
$$

Note:

$\mathrm{BAD}=$ Biological Asset Disclosure

$\mathrm{BAI}=$ Biological Asset Intensity

$\mathrm{NP}=$ Firm Performance

$B=$ Regression Coefficient

$e=$ error 
The Role of Biological Assets Disclosure and Biological Asset Intensity ...

Hypothesis 1 is accepted if the sig value is smaller than alpha $(0,05)$ and the regression coefficient $(\beta)$ is positive (on equation 1 ). Hypothesis 2 is accepted if the sig value is smaller than alpha $(0,05)$ and the regression coefficient $(\beta)$ is positive (on equation 2 ). Besides that, Hypothesis 3 is accepted if the sig value is smaller than alpha $(0,05)$ and the regression coefficient $(\beta)$ is positive (on equation 3 ). In Hypothesis 4 , the biological asset disclosure mediates if equations 1 and 3 are positive, and the regression coefficient is positive as well. The statistical test instrument utilized SPSS Process version 20. Besides, this study also assessed the data quality using the classical assumption test.

The independent variable in this research was Biological Asset Intensity. Biological Asset Intensity describes how much the firm's investment in its biological assets. According to Firda (2017), the biological asset intensity was obtained by dividing total biological assets against total firm assets, as measured in the following way:

$$
\text { Biological asset intensity }=\frac{\text { Total of biological assets }}{\text { Total assets }}
$$

The intervening variables in this study were biological assets disclosure. According to the Indonesian Financial Accounting Standards Guidelines 69, biological assets are analyzed employing content analysis. Firms that disclose biological assets are given a score of 1 , and those that do not disclose are given a score of 0 . Alfiani and Rahmawati (2019) used the Wallace index formula to measure the extent of biological asset disclosure with the following formula:

$$
\text { Biological Asset Disclosure }=\frac{n}{34} \times 100 \%
$$

The dependent variable in this study was firm performance. It was measured using Return on Assets (ROA). ROA is how efficient a firm manages its assets to generate profits in a certain period. Triyani et al. (2018) measured ROA as calculated below:

$$
\text { ROA }=\frac{\text { Net Income }}{\text { Total Assets }}
$$

\section{Result and Discussion}

\section{Descriptive Statistics Test}

The descriptive statistics of variables used in this study is presented in the Table 2 .

Table 2 Descriptive Statistics

\begin{tabular}{lccccc}
\hline \multicolumn{1}{c}{ Variable } & $\mathbf{N}$ & Minimum & Maximum & Mean & Std. Deviation \\
\hline $\begin{array}{l}\text { Biological Asset } \\
\text { Intensity }\end{array}$ & 39 & 0.034 & 0.572 & 0.29169 & 0.14670 \\
$\begin{array}{l}\text { Biological Asset } \\
\text { Disclosure }\end{array}$ & 39 & 0.618 & 0.824 & 0.71408 & 0.04922 \\
\begin{tabular}{l} 
Firm Performance \\
\hline
\end{tabular} & 39 & 0.068 & 0.694 & 0.34338 & 0.18864 \\
\hline
\end{tabular}


The Role of Biological Assets Disclosure and Biological Asset Intensity ...

It can be seen in Table 2 that the data used as the research samples were 39 samples data. Regarding the Biological Asset Intensity (BAI) variable, the minimum value of 0.034 was PT Bumi Teknokultura Unggul (BTEK), the maximum value of 0.572 was PT Gozco Plantation (GZCO), and the (mean) was 0.292. It showed that, on average, the firms invested a relatively small number of biological assets in the firms. Probably, it was due to the initial implementation of the Indonesian Financial Accounting Standards Guidelines 69. The biological Asset Disclosure (BAD) variable had the minimum value of 0.618 owned by PT Bumi Teknokultura Unggul (BTEK), the maximum value of 0.824 by PT Dharma Satya Nusantara (DSNG), and the mean was 0.714 . It revealed that many firms conducted information disclosure on biological assets according to the applicable rules. Besides concerning firm performance (ROA) variable, the minimum value of 0.068 was PT Inti Agri Resources (IIKP), the maximum value of 0.694 was shown by PT Astra Agro Lestari (AALI), and the mean was 0.3433 . Therefore, it could be concluded that the firm performance on agricultural firms was low, as shown in low mean value.

\section{Regression Results}

Table 3 shows that hypothesis $1\left(\mathrm{H}_{1}\right)$ was supported because the sig value $(0.046)$ was smaller than alpha $(0.05)$ and the regression coefficient was positive ${ }^{3}$. It indicated that the biological asset intensity positively affected biological asset disclosure. Moreover, the test shown in Table 4 confirms that hypothesis $2\left(\mathrm{H}_{2}\right)$ was not supported since the sig value $(0.0000)$ was smaller than alpha $(0.05)$. However, its effect was negative so that the biological asset intensity negatively influenced firm performance.

Table 3 Regression Test Result

\begin{tabular}{lrrrrrr}
\hline \multicolumn{1}{c}{ Variable } & B & $\begin{array}{l}\text { Std. } \\
\text { Error }\end{array}$ & T & Sig. & F & Adj.R2 \\
\hline (Constant) & 0.6826 & 0.0169 & 40.4329 & 0.000 & 4.7137 & 0,1035 \\
BAl & 0.108 & 0.052 & 2.067 & 0.046 & & \\
*BAl = Biological Asset Intensity & & & & & \\
\hline
\end{tabular}

Table 4 The Result of Direct Effect of Biological Asset Intensity on Firm Performance

\begin{tabular}{cccc}
\hline Effect & Std Error & $\mathrm{t}$ & Sig. \\
\hline$-0,8640$ & 0,1631 & $-5,2984$ & 0,0000 \\
\hline
\end{tabular}

Table 5 demonstrates that hypothesis $3\left(\mathrm{H}_{3}\right)$ was supported by the sig value $(0.000)$ smaller than alpha (0.05) and the regression coefficient was positive. Hence, the biological asset disclosure positively impacted firm performance.

\footnotetext{
${ }^{3}$ The data processed in this study is free from the problem of classical assumptions. The heteroscedasticity indexed the third regression equation so that the researcher conducted "Heteroscedasticity-Consistent SEs" in Process software to correct the standard error in the OLS regression model.
} 
The Role of Biological Assets Disclosure and Biological Asset Intensity ...

Table 5 Regression Test Result

\begin{tabular}{lcccccc}
\multicolumn{1}{c}{ Variable } & $\mathrm{B}$ & Std. Error & $\mathrm{t}$ & \multicolumn{1}{c}{ Sig. } & $\mathrm{F}$ & Adj.R2 \\
\hline (Constant) & -1.0045 & 0.3364 & -2.9861 & 0.0051 & 25,0800 & 0,5405 \\
BAI & -0.8640 & 0.1631 & -5.2984 & 0.0000 & & \\
BAD & 2.2406 & 0.4596 & 4.8753 & 0.000 & & \\
*BAl = Biological Asset Intensity & & & & & \\
BAD = Biological Asset Disclosure & & & & \\
\hline
\end{tabular}

Table 6 illustrates that hypothesis $4\left(\mathrm{H}_{4}\right)$ was proven. The biological asset disclosure mediated (partially mediation) the correlation between the biological asset intensity and firm performance, as shown by BootLLCI 0.0272 and BootULCI $0.559^{4}$. Both had positive values, meaning that they were significantly positive, as presented in Table 7.

Table 6 The Result of Indirect Effect of the Biological Asset Intensity and Firm Performance

\begin{tabular}{cccc}
\hline Effect & Boot Std. Error & BootLLCl & BootULCl \\
\hline 0,2418 & 0,1304 & 0,0272 & 0,5591 \\
\hline
\end{tabular}

\section{The Effect of Biological Asset Intensity towards Biological Asset Disclosure}

Based on the data regression result, biological asset intensity positively affected biological asset disclosure. This result supported Hypothesis 1. Biological Asset Intensity can be based on the number of biological assets owned by a firm. The proxy of biological asset intensity compares the total biological asset and total assets owned by the firm. The result of this study showed that the biological asset intensity had a positive effect on the biological asset disclosure. The regression test result indicated that the higher the firm's biological asset, the higher the biological assets disclosed. It is in accordance with stakeholder theory, which states that a firm's disclosed information will increase stakeholder's trust. A high biological asset intensity shows that the firm is very confident with the biological asset owned so that the tendency to reveal the biological asset is high.

Biological asset disclosure is a form of manager's responsibility to the stakeholders to fulfill essential information, which eventually will increase the stakeholder's trust in the firm. The higher the firm's biological asset intensity, the more information given by the firm, the more vulnerable it is because it wants to convince investors about its large asset proportion (Firda, 2017). This study's result is in accordance with previous researches conducted by Firda (2017) and Gonçalves and Lopes (2014), which proved that biological asset intensity positively affected biological asset disclosure.

\footnotetext{
${ }^{4}$ The researcher used bias-correlation bootstrap choice for 1.000 resample
} 


\section{The Effect of Biological Asset Intensity towards Firm Performance}

Based on the data regression table, the sig value result for the effect of biological asset intensity towards biological asset disclosure was 0.046 , but it had a negative direction of influence, seen from the coefficient value $\beta-0.8640$. This value showed that the biological asset intensity had a negative effect on firm performance, and hypothesis 2 was not supported. Biological asset intensity is an issue that draws the investor's attention because a firm with a great asset will tend to survive in the future. However, this study's result revealed that the biological asset intensity had a negative effect on firm performance. It contradicts the research by Murah (2017), which stated that the greater asset owned by the firm would increase the firm performance. This result is also different from a study by Gamayuni (2015), which elaborated that the asset proportion had a positive effect on firm performance. Besides, it is inconsistent with the signal theory, stating that the firm that provides information related to its asset will give investors a positive signal related to its performance. A firm with great assets will provide easiness in terms of liability assurance so that the investors will not be anxious if the bank goes to bankruptcy one day.

Nevertheless, the study's result is consistent with research conducted by Triyani et al. (2018), which found that the firm asset proportion had a negative effect on its performance. The more the firm enriched its biological assets, it tended to decrease the firm's performance. It might be affected by some factors. Agricultural firms have main assets in the form of livestock and plants whose benefits cannot be gained directly but through a relatively long process. Therefore, investors tend to be less interested in agricultural sectors since their profit cannot be felt directly. When a firm improves its asset, it can increase the budget needs in running the operational activities so that the firm tends to retain its profit to fulfill the asset needs than the investors' welfare.

\section{The Effect of Biological Asset Disclosure towards Firm Performance}

Based on table 6, the sig value showed that the biological asset disclosure had a positive effect on firm performance, seen from the sig value (0.000) smaller than alpha (0.05) and the regression coefficient was positive. Therefore, this result supported Hypothesis 3.

A firm that allocates investment into firm assets indicates that it is continuously making efforts to increase its assets. Hence, the firm with high biological assets proportions will conduct broader information disclosures to increase investors' trust regarding activities carried out. It has an impact on improving the firm performance because the investors will buy firm shares based on their belief that the firm will grow by considering the activities done. The higher the firm discloses information based on its biological asset proportion, it will improve firm performance.

The study's result is consistent with research conducted by Latupono (2015), showing that biological asset disclosure affected firm performance in Indonesia. Besides, a study's results conducted by Rahayu and Sari (2018) revealed that biological asset 
disclosure influenced firm performance in multinational firms in Malaysia. A high information disclosure related to biological assets conducted by the firm indicates that the firm is confident that it is a positive signal in increasing the firm's profits.

\section{Biological Asset Disclosure Mediates the Correlation between Biological Asset Intensity and Firm Performance}

As shown by BootLLCI 0.0272 and BootULCl $0.559^{5}$, hypothesis $4\left(\mathrm{H}_{4}\right)$ was supported. The biological asset disclosure mediated (partial mediation) the correlation between biological asset intensity and performance. In this case, the signal theory explains that to improve its performance, a firm sends a positive signal to investors through its activities report to reduce asymmetric information. Giving information reports also improves firm performance since firm disclosure has increased the relation between firm and stakeholders, thereby the firm performance increases as well. It is in accordance with the stakeholder theory. This study is in line with researches conducted by Latupono (2015). Besides, this study's result correlates with the research conducted by Ayu and Suarjaya (2017), which stated that information disclosure had a role in intervening in the effect of biological asset intensity advancement towards firm performance. The higher the firm invests in biological assets, the higher the firm performance, according to the stakeholder's point of view. Information reports containing the improvement of proportional asset value and the sizeable biological asset will affect its financial report quality. The report will be used by the investors as the consideration to have an investment decision. Those two reports can describe a good business prospect in the future so that it can provide a positive signal for the investors, and eventually, it affects the increased stock price and firm performance.

\section{Conclusion}

Based on the study results, it could be concluded as follows: First, the biological asset intensity positively affected biological asset disclosure. Second, the biological asset intensity had a negative effect on firm performance. It indicated that the greater the biological asset, the firm performance would decrease. Third, biological asset disclosure positively influenced firm performance. Fourth, the biological asset disclosure could intervene in the correlation between biological asset intensity and firm performance.

This study contributes to the academic field as reference material for research on the topic of biological asset disclosure in the future. In the practice field, this study serves as a material consideration for managers and corporate stakeholders in making corporate decisions to improve firm performance. On the other hand, this study also helps the standard board see the biological asset disclosure in Indonesia considerably and develop the Indonesian Financial Accounting Standards Guidelines 69.

\footnotetext{
${ }^{5}$ The researcher used bias-correlation bootstrap choice for 1.000 resample
} 
The Role of Biological Assets Disclosure and Biological Asset Intensity ...

This study's limitation is that the performance measurement only employed one proxy and did not add assessments using other performance proxies. The future research can develop the model employing a moderated mediation since literature reviews related to this topic is still limited. This research was only able to explain $0.9 \%$ and $24.8 \%$, so it has not been able to explain the factors opposing biological asset disclosure and firm value. This study used the Indonesian Financial Accounting Standards Guidelines 69, which is relatively new for firms that effectively implement these regulations. Further research can add other factors predicted to influence biological asset disclosure or be a consequence and benefit for firms that disclose their biological assets widely. Besides, to determine the effect of applying the Indonesian Financial Accounting Standards Guidelines 65 more efficiently, further research can also utilize the latest timeconsuming application of the Indonesian Financial Accounting Standards Guidelines 69 in the future.

\section{Acknowledgment}

We thank the attendees of the International Conference on Accounting \& Business Management (ICAbM) 2019 in Bandung for their helpful comments.

\section{References}

Alfiani, L. K., \& Rahmawati, E. (2019). Pengaruh Biological Asset Intensity, Ukuran Perusahaan, Pertumbuhan Perusahaan, Konsentrasi Kepemilikan Manajerial, dan Jenis KAP Terhadap Pengungkpan Aset Biologis (Pada Perusahaan Agrikultur yang Terdaftar di Bursa Efek Indonesia Periode 2014-2017). Reviu Akuntansi Dan Bisnis Indonesia, 3(2), 163-178. https://doi.org/10.18196/rab.030243

Alvionita, I., \& Taqwa, S. (2015). Pengaruh Struktur Kepemilikan Dan Mekanisme Corporate Governance Terhadap Tingkat Kepatuhan Mandatory Disclosure. Seminar Nasional Ekonomi Manajemen dan Akuntansi (Snema) Fakultas Ekonomi Universitas Negeri Padang. Retrieved from https: $/ / \mathrm{www} . \mathrm{google} . \mathrm{com} / \mathrm{url}$ ? sa $=\mathrm{t} \& \mathrm{rct}=j \& \mathrm{q}=\& \mathrm{esrc}=\mathrm{s} \&$ source $=\mathrm{web} \& \mathrm{~cd}=\& \mathrm{cad}=\mathrm{rja}$ \&uact $=8 \& v e d=2 a h U K E w j s p b 3 D 2 M T r A h U V V H 0 K H V c u A M U Q F j A A e g Q I B R A B \&$ url $=$ http $\% 3 \mathrm{~A} \% 2 \mathrm{~F} \% 2 \mathrm{Ffe}$.unp.ac.id $\% 2 \mathrm{Fsites} \% 2 \mathrm{Fdefault} \% 2 \mathrm{Ffiles} \% 2 \mathrm{Funggahan} \% 2 \mathrm{~F} 25$ $\% 2520$ Intan $\% 2520$ Alvionita $\% 252 \mathrm{C} \% 2520$ Salma $\% 2520$ Taqwa $\% 2520 \% 2528$ hal $\% 252$ 0590-601\%2529 0.pdf\&usg=AOvVaw2cspn8q6G5YBhldYHhLjat

Ayu, D. P., \& Suarjaya, A. A. G. (2017). Pengaruh Profitabilitas pada Nilai Perusahaan dengan Corporate Social Responsibility Sebagai Variabel Intervening. E-Journal Manajemen Unud, 6(2), 1112-1138. Retrieved from https://ojs.unud.ac.id/index.php/Manajemen/article/view/27825

BPS. (2017). Statistik Pertanian 2017. Retrieved from https://www.gov.uk/guidance/bps$\underline{2017}$

Cahyani, R. C., \& Aprilina, V. (2014). Evaluasi Penerapan SAK ETAP dalam Pelaporan Aset Biologis pada Peternakan Unggul Farm Bogor. Jumal Riset Akuntansi Dan Keuangan, 5(1), 14-37. https://doi.org/10.33558/jrak.v5i1.307 


\section{Utami \& Prabaswara}

The Role of Biological Assets Disclosure and Biological Asset Intensity ...

Daly, A., \& Skaife, H. A. (2016). Accounting for Biological Assets and the Cost of Debt. Journal of International Accounting Research, 15(2), 49-51. https://doi.org/10.2308/jiar$\underline{51415}$

Devi, S., Budiasih, I.G.N., \& Badera, I.D.N. (2017). Pengaruh Pengungkapan Enterprise Risk Management dan Pengungkapan Intelectual Capital Terhadap Nilai Perusahaan (The Effect of Enterprise Risk Management Disclosure and Intellectual Capital Disclosure on Firm Value). Jurnal Akuntansi dan Keuangan Indonesia, 14(1), 20-45. http://dx.doi.org/10.21002/jaki.2017.02

Dimitrova, I., \& Velcheva, Y. (2016). Fixed Biological Assets Specifics of Their Reporting and Related Problems. Economic Archive/Narodnostopanski Arbiv, 3(3), 17-33. Retrieved from http://escweb.lib.cbs.dk/login?url=http:// search.ebscohost.com/login.aspx?direct=true\&db=b th\&AN $=117636387 \&$ site $=$ ehost-live\&scope $=$ site

Duwu, M. I., Daat, S. C., \& Andriati, H. N. (2018). Pengaruh biological asset intensity, ukuran perusahaan, konsentrasi kepemilikan, jenis kap, dan profitabilitas terhadap biological asset disclosure. Jurnal Akuntansi \& Keuangan Daerah, 13, 1-30. Retrieved from http://jurnal.ubl.ac.id/index.php/jak/article/view/1288

Farida, I. (2013). Analisis Perlakuan Akuntansi Aset Biologis Berdasarkan International Accounting STandard 41 Pada PT. Perkebunan Nusantara VII (persero). Jurnal Akuntansi UNES A, 2(1), 1-24. Retrieved from http://jurnalmahasiswa.unesa.ac.id/index.php/jurnalakuntansi/article/view/6500/3407

Firda, A. (2017). Pengaruh Biological Asset Intensity , Ukuran Perusahaan, Konsentrasi Kepemilikan, dan Jenis KAP Terhadap Pengungkapan Aset Biologis (Pada Perusahaan Agrikultur yang Terdaftar di Bursa Efek Indonesia Periode 2012-2015). Simposium Nasional Akuntansi XX. Retrieved from http://scholar.unand.ac.id/27207/

Freeman, R.(1984). Strategic Management: A Stakeholder Approach. Boston: Pitman.

Gamayuni, R. R. (2015). The Effect Of Intangible Asset, Financial Performance and Financial Policies on The Firm Value. International Journal of Economics and Financial Issues, 4(01), 202-212. Retrieved from https: $/ /$ www.google.com/url? sa $=t \& r c t=j \& q=\& e s r c=s \&$ source $=w e b \& c d=\& c a d=r j a$ \&uact=8\&ved=2ahUKEwiG6fXr2sTrAhUUyzgGHYC0DWkQFjAAegQIARAB\&ur l=http $\% 3 \mathrm{~A} \% 2 \mathrm{~F} \% 2 \mathrm{Fwww} . \mathrm{ijstr} .0 \mathrm{rg} \% 2 \mathrm{Ffinal}$-print $\% 2 \mathrm{Fjan} 2015 \% 2 \mathrm{FThe}$-Effect-OfIntangible-Asset-Financial-Performance-And-Financial-Policies-On-The-FirmValue.pdf\&usg=AOvVaw2Xyl1 mT1AMfOVF3rxKVW7K

Gonçalves, R., \& Lopes, P. (2014). Firm-specific Determinants of Agricultural Financial Reporting. Procedia Social and Behavioral Sciences, 110, 470-481. https://doi.org/10.1016/j.sbspro.2013.12.891

Jensen, M. C., \& Meckling, W. H. (1976). Theory of the Firm : Managerial Behavior, Agency Costs and Ownership Structure Theory of the Firm : Managerial Behavior, Agency Costs and Ownership Structure. Journal of Financial Economics, 3, 305-360. https://doi.org/10.1016/0304-405x(76)90026-x

Kim, D. S., Yeo, E., \& Zhang, Y.-A. (2017). Corporate Governance and Firm Value: The Impact of Corporate Social Responsibility. The Korean Journal of Policy Studies, 32(2), 2361. Retrieved from https://www.kci.go.kr/kciportal/main.kci?locale $=$ en

Kim, W. S., Park, K., \& Lee, S. H. (2018). Corporate social responsibility, ownership structure, and firm value: Evidence from Korea. Sustainability (Switzerland), 10(7), 1-20. https://doi.org/10.3390/su10072497

Korompis, C. W. M. (2016). Analisis Perlakuan Akuntansi Agrikultur Pada Petani Kelapa Pada Desa Di Daerah Likupang Selatan : Dampak Rencana Penerapan Ed Indonesian 


\section{Utami \& Prabaswara}

The Role of Biological Assets Disclosure and Biological Asset Intensity ...

Financial Accounting Standards Guidelines No.69 Tentang Agrikultur. Jurnal Riset Akuntansi Going Concern, 11(2), 23-33. https://doi.org/10.32400/gc.11.2.13058.2016

Kurniawan, R., Mulawarman, A. D., \& Kamayanti, A. (2015). Biological Assets Valuation Reconstruction: A Critical Study of IAS 41 on Agricultural Accounting in Indonesian Farmers. Procedia - Social and Behavioral Sciences, 164(August), 68-75.

https://doi.org/10.1016/i.sbspro.2014.11.052

Latupono, S. S. (2015). Pengaruh Corporate Social Responsibility Terhadap Nilai

Perusahaan: Good Corporate Governance Variabel Moderating. Jurnal Ilmu Dan Riset Akuntansi, 4(8), 1-15.

Murah. (2017). Analisis Pengaruh Struktur Aset dan Kebijakan Deviden terhadap Nilai Perusahaan. Journal Ilmiah Rinjani, 5, 143-155. https://doi.org/10.12345/jir.v5i2.12

Natasari, D., \& Wulandari, R. (2018). Akuntansi Aset Biologis : Perlukah Adopsi International Public Sector Accounting Standard ( Ipsas ) 27 Dalam Standar Akuntansi Pemerintahan ( SAP )? Jurnal Gama Societa, 1(1), 71-79.

https://doi.org/10.22146/igs.34051

Owusu-Ansah, S. (1998). The impact of corporate attributes on the extent of mandatory disclosure and reporting by listed firms in Zimbabwe. The International Journal of Accounting, 33(5), 605-631. https:// doi.org/10.1016/s0020-7063(98)90015-2

Rahayu, M., \& Sari, B. (2018). Faktor-Faktor Yang Mempengaruhi Nilai Perusahaan. Ikhrait Humaniora, 2(74), 69-76. Retrieved from https://journals.upiyai.ac.id/index.php/ikraith-humaniora/article/view/73

Sawarjuwono, T., \& Kadir, A. P. (2003). Intellectual Capital : Perlakuan, Pengukuran dan Pelaporan. Jumal Akuntansi dan Keuangan, 5(1), 35-57. https://doi.org/10.9744/jak.5.1.pp.\%2035-57.

Sejati, B. P., \& Prastiwi, A. (2015). Pengaruh Pengungkapan Sustainability Report Terhadap Kinerja dan Nilai Perusahaan. Diponegoro Journal of Accounting, 0(1), 195-206. Retrieved from https:// ejournal3.undip.ac.id/index.php/accounting/article/view/15848

Selahudin, N. F., Firdaus, F. N. M., Sukri, N. S. A. M., Gunasegran, S. N., \& Rahim, S. F. A. (2018). Biological Assets : The Determinants of Disclosure. Global Business and Management Research: An International Journal, 10(3), 170-179. http://dx.doi.org/10.33087/ekonomis.v4i1.114

Seng, D., \& Su, J. (2010). Managerial Incentives Behind Fixed Asset Revaluations : Evidence from New Zealand Firms. Department of Accountancy and Business Law, 3(3), 1-33.

Retrieved from https: $/ /$ www.google.com/url? $\mathrm{sa}=\mathrm{t} \& \mathrm{rct}=i \& \mathrm{q}=\& \mathrm{esrc}=\mathrm{s} \&$ source $=$ web\&cd $=\& \mathrm{cad}=\mathrm{rja}$ \&uact $=8 \& v e d=2 a h U K E w i W 6 v b S 3 c \operatorname{Tr}$ AhUNSX0KHdi1AaYQFjABegQIAhAB\&url $=$ https $\% 3 \mathrm{~A} \% 2 \mathrm{~F} \% 2 \mathrm{Fourarchive.otago.ac.nz} \% 2 \mathrm{Fbitstream} \% 2 \mathrm{Fhandle} \% 2 \mathrm{~F} 10523 \% 2 \mathrm{~F} 1$ 606\%2FSeng Fixed Asset Revaluations -

submit to Illinoi.pdf\&usg=AOvVaw0R0rVc3wTSxEL3eKdLa1YV

Setiawan, S. R. D. (2017). Terus Turun, Pangsa Pertanian terhadap Perekonomian Nasional. Kompas. Retrieved from

https://money.kompas.com/read/2017/03/30/190607926/terus.turun.pangsa.pertan ian.terhadap.perekonomian.nasional

Silva, R., Nardi, P., \& Ribeiro, M. (2015). Earnings Management and Valuation of Biological Assets. Brazilian Business Review, 12(4), 1-26. https://doi.org/10.15728/bbr.2015.12.4.1

Sissandhy, A. K., \& Sudarno. (2014). Pengaruh Kepemilikan Asing Terhadap Nilai Perusahaan dengan Pengungkapan Corporate Social Responsibility Sebagai Variabel Intervening. Diponegoro Journal of Accounting, 3(2), 1-7. Retrieved from https://ejournal3.undip.ac.id/index.php/accounting/article/view/6084 


\section{Utami \& Prabaswara}

The Role of Biological Assets Disclosure and Biological Asset Intensity ...

Spence, M. (1973). Job Market Signaling. Quarterly Journal of Economics, 87(3), 355-374.

Retrieved from http://links.jstor.org/sici?sici=0033-

5533\%28197308\%2987\%3A3\%3C355\%3AJMS\%3E2.0.CO $\% 3 B 2-3$

Triyani, W., Mahmudi, B., \& Rosyid, A. (2018). Pengaruh Pertumbuhan Aset terhadap Nilai Perusahaan dengan Profitabilitas sebagai Variabel Intervening (Studi Empiris Perusahaan Sektor Pertambangan yang Terdaftar di Bursa Efek Indonesia Periode 2007-2016. Tirtayasa Ekonomika, 13(1), 107-129. http://dx.doi.org/10.35448/ite.v13i1.4213

Wulandari, R., \& Wijayati, F. L. (2018). Analisis Perlakuan Akuntansi Aset Biologis Pada Perusahaan Sektor Agrikultur Subsektor Perkebunan Yang Terdaftar Di Bursa Efek Indonesia (BEI). Riset Akuntansi dan Keuangan Indonesia, 3(2), 139-157. https://doi.org/10.23917/reaksi.v3i2.6619

Yurniwati, Y., Djunid, A., \& Amelia, F. (2018). Effect of Biological Asset Intensity, Firm Size, Ownership Concentration, and Type Firm against Biological Assets. The Indonesian Journal of Accounting Research, 21(1), 121-146.

https://doi.org/10.33312/ijar.338 